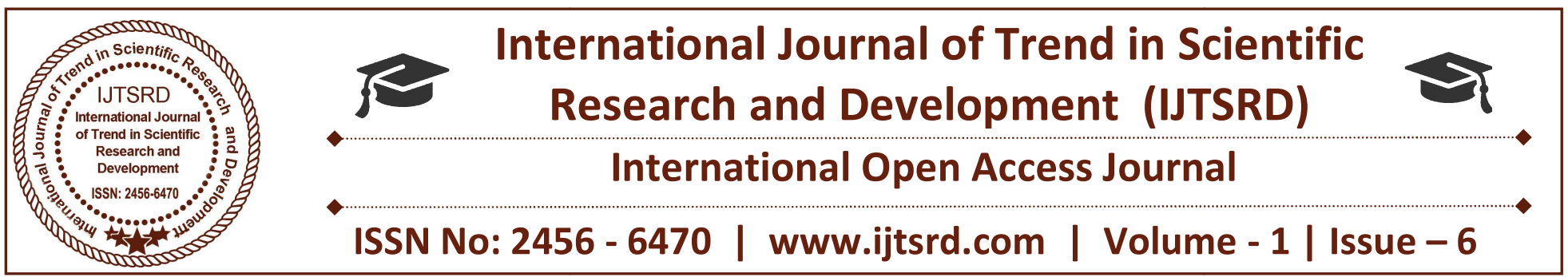

\title{
Redefining Education in Africa, 'The Need for Sustainable Development through Innovative and Creative Learning',
}

Tani Emmanuel Lukong

Ph.D., Lecturer and Researcher, University Of Buea, Cameroon
Sr. Therese Nyia Njamfa

Ph.D, Catholic University Of Cameroon

(CATUC), Bamenda

\section{MICAH Ezekiel Elton Micheal}

Ph.D., Departments of Business Administration, Faculty of Administration, Nasarawa State University Keffi, Nigeria

\begin{abstract}
Redefining education in Africa is a process that has existed over the years with the hope of addressing African realities through reviewing western orientations that dominate educational systems and practices in Africa. The past two decades have seen the emergence of a global movement that calls for a new model of learning for the twenty-first century. There is now a significant body of literature focusing mainly on three topics motivations for a new model of learning, the specific competencies and skills needed for learners to function effectively in the twenty-first century, and the pedagogy required to stimulate those capabilities. Most African countries are still grappling and yet to understand and promote learning that can foster sustainable development. This policy driven conceptual paper identifies multiple drivers working to transform the content that African learners need to be taught and the methods for teaching and learning. Conceptualizations from Experts offered diverse reasons for the need to transform learning content and pedagogy of most African countries. Persistent disengagement among youth and high early dropout rates in African have increased calls for schools to become more relevant. Changing views on the merit
\end{abstract}

of formal education and emerging student characteristics are also challenging the value of the curriculum in most African states. Shifts in labour market trends and skills shortages in most African workforce have highlighted widening inadequacies in students' preparedness to tackle twenty-first century challenges. Growing concern about potential economic and global crises ahead have also led many to question whether today's African learners possess the combination of critical thinking, creativity, collaborative, and communication skills necessary to tackle future shifts in the marketplace. This paper explores these factors in depth and offers a sound rationale for redefining twenty-first century learning content and pedagogy in most African countries. Recommendations for educational planning and policy, curriculum development and teacher training dynamics were proposed for consideration.

Keywords: Education in Africa, Innovative and Creative learning, and Sustainable Development 


\section{INTRODUCTION}

Redefining education in Africa is a process that has existed over the years with the hope of addressing African realities through reviewing western orientations that dominate educational systems and practices in Africa. Traditional Africa had an informal education, which at the time was (and still is) very effective, yet to the colonial masters the system was not equipped to address colonial expectations. They established colonial education; its main object was the spread of colonial culture. This system did not only eradicate African knowledge systems, values, and practices but also did not match African educational philosophy, values, and social thoughts. This alien process was completely divorced from the African worldview as concerns its cultural and contextual realities. Becoming independent did not mean Africans were equipped to face emerging social, economic and political challenges. Today, the African society is experiencing change of values and modern economic process demands a range of skills which should offer far more opportunities to the average African for self-development. Consequently, Africa is in need of a more fluid economy for world competition. It should be able to cope with technological change as a function of globalisation. Africans need to be open minded, the economy and society should be flexible and open to embrace change, and this requires persons who are reflective, imaginative, and problem solvers. These cumulative demands require adequate education systems.

Accordingly, twenty-first century Africa needs to review its educational offerings from all perspectives, and at all levels. This process needs to address the question concerning the profile of the twenty-first century African person who should be creative, independent, and able to lead full and happy lives, earn their own living, as well as and keep up with a rapidly changing society. To mark societal and economic are change which is a function of rapid globalization, Africans need to be much more resilient and skilful. Africa therefore is undergoing change like the rest of the world; thus, there is urgent need for a new form of education that is process oriented, characterized by quality, quantity, equity, relevance, and inclusivity with outcomes that are transformative. The issue arising from the above inference is the type of education that can lead twenty-first century Africa to sustainable development. Education is key to global integrated framework of sustainable development goals (UNESCO, 2015). More important is the fact that education is at the heart of all efforts to adapt to change and to transform the world within-(UNESCO, 2015, p3). Education for Africa today and tomorrow requires some stocktaking on how African education systems have responded to all the international frameworks and declarations in relation to its offerings, reflecting African realities. Such reflection also gives directives on how education should build capacity for Sustainable Development particularly in Goal 4 with all its expectations.

\section{Background to the Problem}

Preparing learners for life, citizenship, and work in the twenty first century is daunting. Globalization, new technology, migration, international competition, changing markets, and transnational environmental and political challenges all drive the acquisition of skills, knowledge, and attitudes needed by students to survive and succeed in the twenty-first century. Educators, education ministries, governments, foundations, employers, and researchers refer to these abilities as twenty-first century skills, higher-order thinking skills, deeper learning outcomes, complex thinking, and communication skills. Interest in these skills is not new; researchers at Harvard University have been studying student learning processes and approaches to teaching higher-order skills for over forty years (Saavedra and Opfer, 2012).

One of the greatest international conference that have shaped educational reforms and policies for sustainable development in Africa is the World Education Forum, held in Dakar from 26 to 28 April 2000. The forum culminated in the formulation of Education for All (EFA) goals that were initiated in Jomtien, Thailand, in 1990. EFA 2000 assessment, is the largest evaluation of education ever undertaken, attended by 164 countries, including most countries of sub-Saharan Africa (UNESCO, 2000). The participants of the conference came up with 6 educational goals. Though, the EFA goals laid emphasis on equity and quality education, the declaration focused more on the content without a clear and precise description of the process to achieving equity and quality. The declaration also was not explicit on the integration of cultural assets (indigenous knowledge systems) in schools, which is an important aspect of knowledge creation. The declaration did not address fundamental epistemological issues mentioned above. A declaration of such magnitude need to convey well 
spelt out roles, responsibilities, and accountability for various aspects of the implementation. It is therefore not surprising that according to the Education for All Global Monitoring Report (UNESCO, 2015) no country in sub-Saharan Africa achieved the EFA goals and only seven countries in the region achieved even the most watched goal of universal primary enrolment. Sixteen of the twenty lowest ranked countries in progress towards 'Education for All' are in sub-Saharan Africa (UNESCO, 2015).

In 2015, the world education leaders and stakeholders met in another World Education Forum at Incheon in the Republic of Korea, to come up with an agenda for sustainable education to be achieved by 2030 . The post-2015 sustainable development agenda highlighted seventeen sustainable development goals to run from 2015-2030. Education stands alone as goal 4 aims at ensuring inclusive and equitable quality education and promotes life-long learning opportunities for all. It equally needs to serve as a strategy towards the realization of all other development goals. Education has been viewed as the driving force that permeates all other goals therefore it should "addresses the interdependence of environment, economy, society, and spearhead the fundamental change of mind-sets needed to trigger action for sustainable development" (UNESCO, 2015: 11). Humanistic education is considered valuable because it takes cognisance of "human rights and dignity, social justice, inclusion, protection, cultural, linguistic, ethnic diversity, shared responsibility, and accountability" (UNESCO, 2015: 6). The Incheon declaration (a project in progress) seems to have covered the cultural and linguistic diversity concerns necessary to sustainable development. Nonetheless, there is little or no monitoring mechanisms to make sure that individual government in Africa are effective in the implementation of the SDGs. It would appear the Incheon declaration, like the Dakar declaration is another paper policy that does not clearly spell out issues relating to individual government's accountability in failure to implement the policy.

One of the latest African Unions reforms is the Agenda 2063, with the mission of transforming the continent into a prosperous, integrated, secure and peaceful, democratic, and dynamic force in the world. Agenda 2063 acts as a roadmap for the development of a peaceful continent, integrated, prosperous and people-oriented. It defines strategic steps to achieve this mission through a prompt well strategized vision in the shortest possible time through a Continental Education Strategy for Africa (CESA 2016-2025). The main goal of CESA is to re-orientate Africa's education and training systems to meet the knowledge, competencies, skills, innovation and creativity required to nurture African core values and promote sustainable development at the national, subregional and continental levels. Those responsible for its implementation will be assigned to " reorient Africa's education and training systems to meet the knowledge, competencies, skills, innovation and creativity required to nurture African core values and promote sustainable development at the national, subregional and continental levels" (CESA 2016-2025). CESA has clearly outlined 6 guiding principles, 7 pillars and 12 strategic objectives that imply the need for integration of cultural assets and indigenous knowledge systems in formal education. These are open for implementation at regional and country levels.

While the global and regional educational policies in Africa continue to make progress in content one can clearly highlight the fact that these policies lacks proper implementation strategies. Hence they remain superficial without any practical bearing to the lives of Africans. Access, Equity and Inclusion, Language/medium of instruction and Integration of Information Communication Technology represent such closely related trends. Driven by technology, globalisation is leading to closer economic integration in Africa and, in many cases, to widening disparities and inequalities within and between countries. The development of education in Africa off course is receiving renewed interest through research collaboration and innovative approaches to learning. African Governments and the private sector alike have articulated concern over the need to expand access to relevant and good-quality education, particularly in Sub-Saharan Africa (SSA). Such renewed commitment has in general terms come as a result of three confluent factors.

First, the expansion of primary education has been propelled by Education for All initiatives (EFA) and the Millennium Development Goals (MDG). Many of the countries that have committed themselves to the attainment of EFA and MDG goals have moved towards high Gross Enrolment Rates (GER) for primary education. But higher enrolment rates in primary schools have increased pressure on secondary schools, and attempts to expand secondary education 
have resulted in deterioration in quality. Second, expansion also appears necessary because the secondary education curriculum has lost some of its relevance. The need for a more sophisticated labour force equipped with appropriate competencies, knowledge, and workplace skills is increasing in many economies, coupled with the need for such labour to be available globally. Far from being an end to itself, education rather aims at paving the way to higher heights of independence such as enable graduates to operate small and large scale businesses as well as find employment without further qualifications. The current education curriculum does not gear toward achieving the latter and beyond. Third, the need for a renewed commitment results from the critical role a well-educated young generation can play in enhancing democracy, human rights, rule of law, good citizenship as one outcome of a good education (Aw \&Mariro, 2001).

Based on the provisions of the above international conventions with regards to educational policies, it is apparent that there is the need to establish an important link between the cultures of a people, their indigenous knowledge systems and curriculum content in formal educational settings. More so, it is also very necessary to consider all participants in various communities in the process of knowledge creation and learning. According to Obanya (2006), one very heartening development of the current century is that education has returned to the desired emphasis on personality development. This is mainly because today's knowledge economy requires more of knowledge workers than manual workers, more of creative workers than mere productive workers. The emphasis will no longer be on what one has learned but on how ready one is to learn. The knowledge worker of today needs a constellation of intrapersonal and inter-personal skills. Traits like perseverance, capacity for strategic thinking, versatility and adaptability belong to the realm of intra-personal skills, while communicative ability and team spirit belong to the realm of inter-personal skills, while IT-fluency is a transversal skill. These are the tools for survival in today's world of work. They should therefore be given due prominence in education policy and practice. The major implication of the personality development approach to education is that it contributes to a de-loading of the curriculum, as content yields place to processes. It also transforms the teacher into a learning process manager.

\section{CONCEPTUAL AND EDUCATIONAL POLICY ISSUES}

\section{Drivers of Change}

The complexity of the present and future world means that learners must be equipped to navigate unexpected challenges ahead. Key drivers and challenges are redefining the competencies and skills that learners need to develop. These forces represent significant disruptive shifts that are likely to reshape the future landscape of education and work, and produce changes in the way people learn. These include drivers based on demographics, globalization trends, labour market fluctuations, environmental forecasts, and the pressures of immigration and their consequences for school curricula and pedagogy. The evolving sophistication of technology, global connectivity and new social media must also be taken into account when imagining the forms that twentyfirst century learning may take (Davies, Fidler and Gorbis, 2011; Leadbeater and Wong, 2010; Redecker 2011). New Competencies for a complex world the twenty-first century promises uncertainty and complexity, and little respite is expected in the scale or pace of change (Carneiro, 2007).

This complex environment rewards people with 'inclusive competencies, such as the ability to make local-to-global connections, recognize differing perspectives, and think critically and creatively to solve global challenges, and collaborate respectfully in different types of social forums' (P21, 2007). Sawyer (2006) emphasizes the importance of preparing youth for these varying futures and collaborating across cultures to address likely environmental, sociological and political difficulties. Learning how to 'understand, adapt to and prosper in these turbulent times has become a critical competence' (Carneiro, 2007). The world is becoming more interconnected and complex, and will require multifaceted responses. The response of education to these challenges will play a singular and active role in shaping the future. The needs of twenty-first century citizenship must also be addressed and aligned with the development of twenty-first century skills. To make informed decisions and contribute responsibly at local, regional and national levels as informed voters and citizen advocates, youth must be prepared to tackle matters ranging from economics and geopolitics to cultural and social developments, as well as environmental and health concerns (p21, 2013). 


\section{Changing Student Characteristics}

Another driver for change is learners themselves their preferences, needs, social habits, and technology choices. University student profiles show that a large proportion of learners work and study online, expect continuous Internet connectivity and web-based services, and regard social networks as vital to their lives (Windham, cited in McLoughlin and Lee, 2010, p. 4). Conole and Creanor (cited in McLoughlin and Lee, 2010) report that today's students 'have high expectations of how they should learn, selecting the technologies and learning environments that best meet their needs with a sophisticated understanding of how to manipulate these to their advantage' (p. 3). Today's learners pursue learning by exploring, expressing, and exchanging ideas using technological means (BenDavid Kolikant, 2010), often tinkering and using trial and error to try different strategies until they arrive at solutions (Papert, cited in Ben-David Kolikant, 2010; Facer, 2011).

\section{New Approaches for Learning}

To support learners' development of 21 st century skills as reflected in the general capabilities of the African Curriculum, we need to create and sustain knowledge-building environments. New technologies such as smart devices (e.g., tablets and smart phones) and personal learning environments can be used in conjunction with contemporary knowledge building strategies, leading to greater innovation in learning. To support new ways of learning, students need access to appropriate resources and assessment that allows them to demonstrate skills such as reasoning, problem solving and designing. Teachers will need development and support to deliver these new ways of learning. Enhancing teacher capability is key to accelerating successful digital education in schools.

\section{Encouraging school learning and teaching plans}

It is important to recognise that schools are at different stages in their development of digital capacity and hence have different needs. Accordingly, each school's learning and teaching plan must demonstrate how they will increase the capacity to support students' learning of twenty-first century skills; support leadership of contemporary pedagogies; build teacher capabilities; connect learning beyond the school and sector; broaden student assessment and reporting; and, improve the provision, accessibility and management of teaching and learning resources. The development of individual plans by schools would provide a structured framework to accelerate the uptake of digital education in schools. The plans could include procedures for collection, analysis and exchange of student data and digital content, and include the schools polices and processes it has or will have in place addressing risk assessment, cyber safety, responsibilities and accountability.

\section{REDEFINING THE QUALITY AND RELEVANCE OF LEARNING IN AFRICA}

Preparing learners for work, citizenship and life in the twenty first century is daunting. Globalization, new technologies, migration, international competition, changing markets, and transnational environmental and political challenges all drive the acquisition of skills and knowledge needed by students to survive and succeed in the twenty-first century. Educators, education ministries and governments, foundations, employers and researchers refer to these abilities as twenty-first century skills, higher-order thinking skills, deeper learning outcomes, and complex thinking and communication skills. The complexity of the present and future world means that learners must be equipped to navigate unexpected challenges ahead. Key drivers and challenges are redefining the competencies and skills that learners need to develop. These forces represent significant disruptive shifts that are likely to reshape the future landscape of education and work, and produce changes in the way people learn. These include drivers based on demographics, globalization trends, labour market fluctuations, environmental forecasts, and the pressures of immigration and their consequences for school curricula and pedagogy. The evolving sophistication of technology, global connectivity and new social media must also be taken into account when imagining the forms that twenty-first century learning may take (Davies, Fidler and Gorbis, 2011).

One of the challenges faced by efforts to gain professional status for teachers is that teaching is complex work that looks deceptively simple. Having spent considerable time in classrooms, parents and policymakers have had ample opportunities to observe classroom teaching. And in their roles as parents, lay teachers in religious schools, employers, etc. most of them have taught others. An argument for the complexity of classroom teaching thus requires an analysis of what differentiates the kind of informal teaching human beings engage in all the time from the instructional activity that occurs primarily in 
classrooms. In an effort to highlight teaching as professional work, researchers in the 1980s focused on the knowledge demands of teaching, arguing that teaching requires a great deal of knowledge that is specific to the work of teaching. Similarly, the work on teachers' subject matter knowledge has tried to differentiate the kind of knowledge a well-educated person might have about a subject from the specialized knowledge of a subject required for teaching (Shulman, 1986).

This emphasis on knowledge has obscured the importance of other aspects of teaching, including the need for skill in orchestrating instructional activities, and the relational work involved in creating classroom communities. Our views of teaching over the past several decades have evolved from an emphasis on teacher characteristics to a focus on teachers' behavior to more recent cognitive views of teachers as decision-makers and reflective practitioners. Teacher education has responded to this final turn toward the cognitive by shifting its focus from skills to knowledge and reflection. While clearly both of these are essential to the work of teaching, we want to argue that teacher education should move away from a curriculum focused on what teachers need to know to a curriculum organized around core practices, in which knowledge, skill, and professional identity are developed in the process of learning to practice (Grossman \& McDonald, 2008).

\section{Changing Perceptions about the Value of Formal Education}

Today, a large proportion of young people drop out of school because they view formal education as irrelevant and become apathetic and disengaged with formal education. There is growing disillusionment with the value of education as a vehicle for social integration and greater well-being with many young people now question the 'return on investment' of traditional 'high-status' educational routes (Facer, 2011; UNESCO 2015). While many factors contribute to student disengagement, there is a general belief that secondary student dropout rates reflect an inability on the part of current education systems to link academic content to real-world experience. The current industrial model of schooling was designed to meet the production needs of a much earlier time and has outlived its usefulness (p21, 2007). Modes of learning have shifted dramatically over the past two decades with changes in the ways people access, exchange and interact with information. Schools have changed far more slowly with the fundamental aspects of learning institutions remaining essentially familiar for 200 years or more (Davidson et al., 2009). Future educational systems are expected to transform from institutions with a strong emphasis on teaching to organizations with an increased emphasis on learning. Recognition of multiple pathways for acquiring skills will follow. Teachers will design challenging learning activities and students will learn anytime or anywhere at a pace comfortable for them, using whichever tools they choose. The roles of teachers will be transformed from experts on subjects to that of guides and coaches (Ericsson AB, 2012; Frey, 2007). Twenty-first century teachers will assess their students' skills and identify and design learning activities to help them achieve deeper understanding. Ongoing formative assessment is most effective for this approach as it allows teachers to adjust their strategies within lessons for maximum effectiveness.

This section addresses the multitude of factors related to the future of learning in the digital age and examines why twenty first century learning must change. Multiple factors are driving change in the way students are educated. Pressures vary from context to context but the message is the same: schools are failing to prepare children for the challenges ahead. Students are not learning adequately under the present education system and are not being equipped with the skills and knowledge to lead satisfying and productive working lives. In addition, nations are losing opportunities to prepare youth for citizenship and the economy is suffering from a lack of innovation. What can be done about this continuing loss of capacity?

\section{Information Communication Systems and the Digital Revolution}

Most African countries are marvelled at the rapid technological advancement in education. The quest for the integration of ICTs in Africans education has become a significant blueprint in most African policy and budget allocations. Information and Communication Technologies (ICT) simply involve technologies arising from scientific, technical and technological progress in computer sciences, electronic and telecommunications. Many countries around the world have established organizations for the promotion of the Information and Communication Technology (ICT) in education. There is, however, a clear gap between technological "have" and "have not" regions. The introduction of ICT in education is 
part of the more fundamental objective to improve education globally and to make it accessible to everyone.

Information and communication technologies (ICT) in African education systems have stirred both excitement and pessimism. For example, ICT has the potential to extend the reach of available teaching and learning resources by means of a single instrument: an Internet-connected computer. More generally, access to ICT has become increasingly indispensable if countries are to develop economically and educate their people. In this capacity, ICT may be considered a critical social issue for African countries that intend to partake in the increasing trend toward global economic and socio-cultural interaction. Nevertheless, the integration of ICT into African education and professional training systems comes with a number of limitations that must be taken into accounts which have been classified into the four following categories:

- Infrastructural challenges: power outages, Internet blackouts

- Technological challenges: insufficient, inadequate, and out dated computer equipment

- Human challenges: lack of techno-pedagogical skills in teachers; lack of techno-pedagogical training

- Financial challenges: lack of permanent funding for pedagogical ICT integration.

In these circumstances, integrating ICT into African education systems is not an easy task. This has led to some divergent views on the topic. Some have simply given up, resigning themselves to wait until sometime in the future when African education systems will be "ready" to integrate ICT as a specific component of a detailed, pre-established development plan. The current discussions on the integration of ICT into African schools are more ideological than empirical. For instance, the idea has been floated that ICT unconditionally and automatically spur development, known as the "technology myth" Tiemtoré (2007). Nonetheless, this work presents a thoughtful overview of the current state of ICT in Africa, challenges they faced, and it presents the views of stakeholders working to integrate ICT into African schools.

There are several explanations for the failure of ICT utilization for pedagogical purposes in certain African educational contexts (Karsenti, et al. 2005). According to Lundall and Howell (2000), the key factors blocking African educational institutions from using microcomputers as teaching and learning tools are insufficient funds, insufficient number of computers, lack of teachers with IT skills, teachers' inability to integrate the computer into the different subject areas, and lack of appropriate microcomputer teaching programmes. In South Africa and most African countries, certain fringe elements of the school age population are using computers for educational purposes at a level comparable to that of developed countries, while the majority of schools in sub-Saharan Africa are still exploring the ways and means of connecting to the Internet, with many in the introduction and launching phase. Although the dearth of structures and the high costs of equipment greatly exacerbate the group usage ratio, all 54 African countries have connected to the internet (Jensen 2002). Clearly, there has been a substantial influx of computer hardware in many lycées and colleges in several African countries. Nevertheless, as revealed in a recent study funded by the IDRC, these investments are not enough to ensure a genuine pedagogical integration of ICT.

Marie Hélène Mottin-Sylla and colleagues (2005) studied six French-speaking African countries (Benin, Cameroon, Burkina Faso, Mali, Mauritania and Senegal) from 2004 to 2005 . They found that, overall; women have much fewer opportunities than men to benefit from the African digital revolution, as they have been allotted the roles of consumers and "helping hands." Their research reveals the scope of the ICT gender divide and voices a plea for greater equality in the digital revolution. In fact, in most African countries, schools have very little computer access time, and rarely at times that are convenient for teachers or students. Since teachers are not very familiar with media use, they often adopt inappropriate pedagogical strategies. Students do not have standardized background knowledge in the different subject areas, nor do they have standardized technological skills or experience with multifaceted learning styles. All these shortcomings impede the pedagogical use of ICT. ICT integration into education also raises new challenges for teachers as students begin handing in assignments lifted straight from the Internet. Aside from the low pedagogical value of such effortless work, teachers must now add exposure and confrontation of plagiarizers to their many other duties. And although teachers bear the burden of proof in such cases, when they are not ICTsavvy, the task becomes practically impossible. 
In many sub-Saharan African countries, there is a real political will to introduce ICT into the education system, but no clearly formulated national ICT policies. Information technology is more or less lumped in with the official school programmes, with no budget allocations for ICT. Funds for ICT equipment and operation generally come out of school fees, fundraising campaigns, and donations from national and international organizations and partners, and in countries like Nigeria and Cameroon, state funding. Meanwhile, the research literature has repeatedly stressed the need to adopt stable, on-going policies and budgets for ICT utilization (Karsenti, et Al. 2005).

However, underdeveloped or even complete absence of telecommunications infrastructure is hampering use of ICTs in rural remote areas (Mandioma, et al. 2007; Adomi, 2005). Broadening the reach and affordability of these technologies and services to rural Africa remains a complex and difficult challenge. This is because terrestrial telecommunications infrastructure requires substantial investments that are often unaffordable for the public sector and don't make economic sense to the private sector (Hasson, 2008). Yet affordable and reliable internet accessibility in poor rural areas will extend the attendant beneficial impacts of ICTs. Nonetheless, all this will depend on a number of key factors. These include: (i) Low-cost, reliable communications infrastructure being built in rural areas. This goes hand in hand with increased awareness of the value-added services brought about by internet connectivity, which will in turn create the requisite demand and justify the massive financial and technological investment. (ii) A supportive and effective legal and regulatory environment being created and maintained, to ensure competitive markets for communication services. (iii) Governments providing incentives to private sector investment that lead to the expansion of affordable internet accessibility to rural areas through a range of proactive policy, regulatory and investment measures, including public-private sector partnerships, where appropriate. The ultimate measure of the value and impact of ICTs in development are the desired outcomes that have a bearing on the Millennium
Development Goals, i.e., reduction in poverty levels, thriving African economies, reduced disease, increased literacy.

\section{NEW AFRICAN PERSPECTIVES FOR SUSTAINABLE DEVELOPMENT}

\section{Drivers Of Change/Transformation In Africa}

The new vision of development in Africa should take into consideration the main drivers of change that can lead to the transformation of education for sustainability. Effective development requires lifelong learning through the creation of more educational spaces that embrace both the formal, nonformal and informal sectors of education. Globalization, digital revolution, urbanization, migration are key elements that affect development in Africa. The role of youth and women as well as the African Diasporas are important facets that must be galvanized for educational transformation in Africa.

\section{Life-long Learning through Formal, Non-formal and Informal Spaces of Education}

From a cultural perspective, education is attained by individuals through informal, non-formal and formal agencies. Such informal, non-formal and formal processes are utilised for the creation and transmission of knowledge, skills, ideas, attitudes and patterns of behaviour.A major part of the cultural heritage of an African people was transmitted to children and adolescents through informal activities, initiated and orchestrated most often by the children themselves. In other words, education was facilitated based on mediated mutual reciprocity tendencies (Tchombe in press) whereby all the stakeholders had equal roles as active participants in the teachinglearning transactional process. Such flexibility that opens windows for enriching children's creativity, curiosity, analytical and imaginative skills and competences do not exist in formal education. Accordingly, there are many best practices that formal education nowadays must learn from informal education in the African cultural contexts. Table 1, below shows an organisational set-up for traditional African education. 
International Journal of Trend in Scientific Research and Development (IJTSRD) ISSN: 2456-6470

Table 1: Organisational Set-Up for Traditional African Education

\begin{tabular}{|l|l|l|l|l|}
\hline SN & Stage of Life & $\begin{array}{l}\text { Educational } \\
\text { Goal }\end{array}$ & $\begin{array}{l}\text { Space and Place of } \\
\text { Education }\end{array}$ & Agencies of Education \\
\hline 1. & Childhood & $\begin{array}{l}\text { Primary } \\
\text { Socialisation }\end{array}$ & $\begin{array}{l}\text { The Home } \\
\text { The Extended family } \\
\text { The Community }\end{array}$ & $\begin{array}{l}\text { Parents } \\
\text { All Older Relations } \\
\text { Elders in the Neighbourhood } \\
\text { The Age Grade } \\
\text { Community Based Organisations }\end{array}$ \\
\hline 2. & Adolescence & $\begin{array}{l}\text { Life Skills } \\
\text { Acquisition }\end{array}$ & $\begin{array}{l}\text { THE COMMUNITY } \\
\text { (all places of work, } \\
\text { recreation, religious } \\
\text { observance, etc. }) \\
\text { The Initiation Ground }\end{array}$ & $\begin{array}{l}\text { Parents } \\
\text { Community Elders } \\
\text { The Age Grades } \\
\text { The Guilds } \\
\text { Secret Societies } \\
\text { Games and Sports Clubs }\end{array}$ \\
\hline 3. & Adulthood & $\begin{array}{l}\text { Social and } \\
\text { Organisational } \\
\text { Skills } \\
\text { Development }\end{array}$ & THE COMMUNITY & $\begin{array}{l}\text { Community rulers and elders } \\
\text { Community Special Service Groups } \\
\text { Special Interest Groupings } \\
\text { The Guilds }\end{array}$ \\
\hline
\end{tabular}

\section{Source: OBANYA (2005:3)}

As shown in table 1 above, the educational system is mapped out to fall in line with the development stages of life. Thus, children receive primary socialisation; adolescents consolidate this and add on life skills, while adults consolidate these two, and add on organisational and social skills. In doing this, special needs are taken care of, as communal life did not allow for exclusion. Even gender perspective was not neglected. Girls and women received education: a common core socialisation in the early years of life, and gender-role-appropriate life skills in adolescence and adulthood. To say that education in African traditional societies is largely informal amounts to telling only a part of the story. Telling the whole story requires that we emphasise the fact that formal, nonformal and informal approaches to education are not dichotomous entities. The three approaches are most of the time inseparable, as there is informal (or incidental) in the process of formal learning. So much formal learning also comes into non-formal learning. The society sets the goals, its normal and organisational patterns determine the mode, and its expectations of a cultured person are the yardstick for the outcomes of education. In principle, this is (or should be) the case in all human societies. Thus, Africa's philosophical worldview and cultural heritage expect the following traits in the educated (or cultured) person.

- Spirituality (and leading the good life in order to be accepted in the life hereafter),

- Full integration into the community, by imbibing its cultural norms and values.

- Acquisition of the life skills necessary for earning a living and contributing to societal life

- Social and organisational skills, for interpersonal relations

The teaching-to-test strategies of current education practices involve a mechanical rush through syllabuses and curricula. Learning through exposure to life experiences is limited, the community has been progressively moving away from the school, and schooled Africans tend to be alienated from their cultural roots. As a result, the possibility of education contributing to the self-regeneration of society is severely limited (Obanya, 2005). In this light, an integrated approach of the different agencies of education (informal, formal and non-formal) is very important for knowledge creation and learning for sustainable development among nations as shown in the table below. 
Table 2: An Integration of Agencies of Education for knowledge Creation/learning for Sustainable Development in Africa

\begin{tabular}{|c|c|c|c|c|}
\hline SN & Agency & $\begin{array}{l}\text { Space and place of } \\
\text { Education }\end{array}$ & $\begin{array}{l}\text { Knowledge } \\
\text { creators/facilitators/stakeholder } \\
\text { s }\end{array}$ & $\begin{array}{l}\text { Cultural assets /skills } \\
\text { learned }\end{array}$ \\
\hline 1. & Informal & $\begin{array}{l}\text {-Home/family milieu } \\
\text {-Peer group setting } \\
\text {-The neighbourhood } \\
\text { setting } \\
\text {-The community setting }\end{array}$ & $\begin{array}{l}\text {-Parents } \\
\text {-Siblings } \\
\text {-Nuclear family members } \\
\text {-Extended family members } \\
\text {-Family friends } \\
\text {-Peers } \\
\text {-Neighbours } \\
\text {-Members of the community } \\
\text { Community resources (persons } \\
\text { and places- libraries, museums) }\end{array}$ & $\begin{array}{l}\text { Storytelling, Proverbs, } \\
\text { Running of errands, } \\
\text { Fetching water, Fetching } \\
\text { wood, Folktales, Games } \\
\text {,Household chores, } \\
\text { Legends, Mythologies, } \\
\text { Riddles/jokes, ,Songs } \\
\text { and dance }\end{array}$ \\
\hline 2. & Non formal & $\begin{array}{l}\text {-The church } \\
\text {-The Mass media } \\
\text {-Government agencies } \\
\text {-Political parties } \\
\text {-Cultural meetings } \\
\text {-Youth movements } \\
\text {-Workshop space for } \\
\text { vocational skills } \\
\text { development }\end{array}$ & $\begin{array}{l}\text {-Clergies } \\
\text {-Adults } \\
\text {-Holy books (bible and Koran) } \\
\text {-News papers } \\
\text {-Radio } \\
\text {-Television } \\
\text {-Computers (cyber space) } \\
\text {-Ministries } \\
\text {-Politicians } \\
\text {-Members of the community } \\
\text {-Children \& youths } \\
\text {-Masters of apprenticeship }\end{array}$ & $\begin{array}{l}\text {-Songs, Proverbs, Dances } \\
\text {-Values } \\
\text {-Intellectual \& technical } \\
\text { skills } \\
\text {-Spiritual, moral and } \\
\text { vocational development } \\
\text {-Cultural traits, } \\
\text { agriculture } \\
\text {-Child care, current } \\
\text { events } \\
\text {-Literacy skills } \\
\text {-Nutrition } \\
\text {-Culture } \\
\text {-Science } \\
\text {-Technologies } \\
\text {-Civil awareness } \\
\text {-Family planning } \\
\text {-Self-reliance }\end{array}$ \\
\hline 3. & Formal & $\begin{array}{l}\text { Schools at all levels } \\
\text {-Pre-primary } \\
\text {-Primary } \\
\text {-Secondary (general, } \\
\text { technical, vocational and } \\
\text { comprehensive) } \\
\text {-Tertiary (universities) }\end{array}$ & $\begin{array}{l}\text {-Parents } \\
\text {-Siblings } \\
\text {-Peer mentors } \\
\text {-Community resources (persons } \\
\text { and places) } \\
\text { - Members of community } \\
\text {-Ministries } \\
\text {-Trained/specialised teachers in } \\
\text { different subjects } \\
\text {-Lecturers/researchers } \\
\text {-Educational technologies (audio, } \\
\text { visual, audio-visuals, print } \\
\text { materials, manipulative, graphics, } \\
\text { models, real things and computer } \\
\text { related technologies) }\end{array}$ & $\begin{array}{l}\text {-Development of } \\
\text { complicated \& } \\
\text { sophisticated skills/ideas } \\
\text { necessary for effective } \\
\text { functioning in society } \\
\text { and the global world } \\
\text {-Literacy skills } \\
\text {-Prepares individuals for } \\
\text { specific jobs \& careers }\end{array}$ \\
\hline
\end{tabular}


Table 2 above illustrates a holistic perspective on the role of education human life cycle. It affirms that learning as a continuous process in life through different agencies and spaces, plays an essential role in enabling individuals to adapt, and manage new challenges as well as changes in their lives and environments. Lifelong learning, embracing all forms of educational and learning experiences, helps individuals to engage in purposeful interactions with their environment... Implicit to the idea of lifelong learning is the concept of 'life wide' learning. While the former emphasizes the continuity of learning throughout human life cycle, the latter recognises that humans find it necessary to engage in multiple learning activities simultaneously, through different modalities and in varying settings. Lifelong learning is intended to enable individuals become active social agents - able to reflect and respond (act) appropriately to the cultural, social and developmental challenges faced as individuals and as members of society (Medel-Añonuevo et al. cited in Ahmed, 2009:7). Life wide learning thus, relates to the multiple and parallel roles of a person in society, as an added dimension of lifelong learning. Therefore, the traditional emphasis on building the foundation of basic knowledge and competencies and acquiring the intellectual and technical tools of learning in the first quarter of life has to be complemented by lifelong learning in a learning society where all participate in and contribute to learning throughout life.

Recognising the complexities of indigenous African knowledge, the work of Semali (1999) in Tanzania, and his African centred dialectic on the interplay of indigenous folk knowledge and modern (Western) curriculum practice in African schools is important to this discussion. Semali conversantly outlined the distinctions between indigenous African knowledge and other forms of knowledge to report that: (1) Indigenous African knowledge (IAK) does not derive its origins or standing from the individual but from the collective epistemological understanding and rationalisation of community; (2) Indigenous African Knowledge is about what local people know and do and what local communities have known and done for generations, (3) the ability to use community knowledge produced from local history form important literacy skills critical to survival in an African context; and (4) what local people know about their environment must be included in the planning and implementation process of education. In addition, and possibly most important theoretically,
Semali introduced the idea of indigenous literacy as information communicated via local culture and languages that reflects local innovations and techniques in activities such as fishing, pest control (via Sudan and Egypt) to herbs, and plant usage to manage local diseases (Semali, 1999:307-308).

African indigenous knowledge has specific implications for sustainable national development, capacity building, and intellectual development. Inclusion of African indigenous knowledge and pedagogies in today's curricula at all levels of the education systems will address relevance and functionality of education (Tchombe, 2009). The euro-centric colonial and post-colonial education excluded the achievements in Africa that include inventions, technologies and an education system that was oriented towards apprenticeship through participation in social and economic activities. As evident therefore, indigenous knowledge and accompanied thought processes proved viable at the level of economic sustainability, self-reliant and costeffectiveness. The African personality is judged from the perspective of social than from cognitive or economic competence because social competence is integral. Missing out such knowledge and understanding of a culture leaves one ignorant of what perceptions of development means and constitute (Tchombe, 2009). In the same light, in the arena of science and technology historically and presently, Africa is generally unrecognised or extremely discounted. This fact is most evident in a simple review of most college and university textbooks; the overwhelming majority do not mention Africa, except for an occasional reference to animal life (nonhuman), mineral sources, or plant life. Consequently, the historical or contemporary African contributions (i.e., state of knowing or understanding) to the identification or investigation of natural phenomena (science), and technology is absent, although research has documented indigenous technology in Africa in many areas that include: manufacturing, agriculture, food processing, civil engineering, transportation, mining, and communication (Sunal, Lynn \& Okebukola,1998:120).

\section{TRANSITION OF LEARNERS FROM CONSUMERS TO PRODUCERS}

This generation of digital tools allows learners to become generators of content (Frey, 2007), instead of passive consumers of knowledge, indicating a preference for active approaches to learning 
(Klamma, Cao and Spaniol, 2007; McLoughlin and Lee, 2010). This change is a consequence of Web 2.0, the name given to the second stage of development of the World Wide Web, which is characterized by the move from static web pages to dynamic or usergenerated content and the growth of social media (Wikipedia, 2014). Web 2.0 sites allow users to interact and collaborate as creators of usergenerated content in a virtual community. This participatory culture provides greater opportunities to initiate, produce and share creations, and to engage in peer-topeer learning. It encourages users to become global citizens, capable of communicating and working in diverse contexts. Examples of user-generated online content include social networking sites, blogs, wikis, video-sharing sites, internet forums or communities, audio and video podcasts, peer-to-peer media-sharing applications, and the use of social and collaborative tagging (Wikipedia, 2014). Video-sharing sites such as YouTube have seen massive growth in users consuming and generating video content, while popular sites such as SlideShare allow users to post and access presentations. Users also create, post and view artwork on sites such as deviantArt and Newgrounds and share mobile photos and videos via pages on Picasa and Flickr (Crompton, 2012; McLoughlin).

In addition, peer-to-peer mediasharing applications and user-created audio-sharing networks such as Sound Cloud, an online audio distribution platform boosting 40 million registered users and 200 million listeners, showcase user-created audio productions. Table 1 in the annex provides specific examples of digital media used by people on a daily basis (Frey, 2012). Web 2.0 has also made possible the building of communities of learners and scholars. Social learning tools such as Second Life facilitate the creation of online study groups in which learners work together. The e-Science movement is offering access to expensive and scarce high-level tools, presenting learners with unique opportunities to engage in the kinds of research conducted by professional scientists. Another example is the Global Hands-On Universe (HOU) programme, which is designed to promote collaborative learning in astronomy; while the Digital Humanities movement offers innovations such as the Decameron Web, which constitutes an excellent example of the Web providing access to scholarly materials and offering students opportunities to observe and emulate scholars at work (Brown and Adler, 2008; Facer and Selwyn, cited in Sharpe,
Beetham and de Freitas, 2010; Punie, 2007). Learners are also capable of creating and generating ideas, concepts and knowledge and are frequently inspired to do so. Blending, remixing and recombining ideas help students to formulate creative solutions. The ultimate goal of learning is to encourage this form of creativity (McLoughlin and Lee, 2008a, p. 8). The move from Web content produced by traditional 'authoritative' sources towards user-generated content is also driving the move from instructor-dominated classrooms and curricula towards more flexible and interactive forms of learning. Students are taking control of their own learning process, making connections with peers, and producing new insights and ideas motivated by a spirit of inquiry (Lee and McLoughlin, 2007).

\section{RECOMMENDATIONS}

$>$ The role of higher education and research in Africa has been identified and recognised as a significant player in facilitating knowledge creation and Africa's development process (NEPAD, 2005). It has however persistently faced several challenges, particularly with growing societal demands. With few resources, inadequate capacity and a history of neglect, the sector has been struggling over the years to respond to these increasing demands, leading to on-going capacity gaps. The sector has also suffered from inadequate funding, weak governance and leadership, low quality academic programmes, and stifled academic freedom (Mohamedbhai, 2008; Sawyerr, 2004). These challenges require urgent intervention for the sector to play a meaningful role, more funding, governance, leadership, and high quality academic programmes that are relevant for sustainable development in most African countries.

The government of different African countries need to facilitate the establishment of accreditation mechanisms for quality assurance of their teacher education systems in the context of: (i) massive expansion; (ii) globalization; (iii) diversified teacher education providers, contents and methods of delivery; and (iv) portability of credits, certification and credentials.

African government (that is, local and urban councils, Non-governmental departments, ministries of Education, Transport, Finance, Defence, National security etc.) need to continuously train workers. Training needsto be a compulsory and compensated policy for all 
personnel in all organizations; this can facilitate access to information flow and reduce unnecessary physical movement of files and personnel from regional headquarters to central headquarters. African Government needs to reduce or eliminate import duties on ICT equipment used for training and learning. This will greatly reduce the prices of hard and software prices currently in Africa and as consequence will motivate people to buy these equipment.

$>$ Curriculum developers need to be congruent with the educational vision, culture, and the context of each region, locally and globally. There is need to develop the vision and standards in stages, starting with a core that can be expanded into a set of standards, implemented with ICTs, for the preparation and continuing professional development of teachers and all educators.

$>$ The ICT curriculum needs to facilitate change toward a more inclusive approach that promotes positive and supportive interdependence between students and teachers, while maintaining individual accountability and autonomy.

$>$ The needs to promote inter-cultural collaboration, and develop a learning community within and between schools and countries, using shared and complementary approaches with languages and cultures.

\section{CONCLUDING REMARKS}

This paper addresses some of the multitude of factors related to the future of learning in this digital age and examines some of the reasons why twenty-first century learning must change. Multiple factors are driving change in the way students are educated, and pressures vary from context to context with a common message: most schools fall short in preparing learners for the challenges ahead. Students need to learn more adequately and are need to be equipped with the necessary skills and knowledge for a more satisfying and productive work life. Rethinking and reconstructing education in terms of knowledge creation and learning for development is an on-going, never-ending process. It works in the context of the present crises, and challenges plaguing education in most African countries, but moves to transcend this by creative integration of past successes with future goals. Several guidelines for educational change can be inferred from the current crisis in Africa. Foremost is the need to tailor external models of curriculum to the needs of all Africans; that is an indigenous reorganisation of education based on existing knowledge systems. African nations need suitable institutions and programs for particular cultural and national needs. Curriculum change should involve teachers, learners, parents, and stakeholders of society at every stage of decision-making; in addition improved in-service training is essential. Curriculum needs to be diversified to be relevant for the great variety of social contexts found in each country. In the light of the complexity of the challenges to education in Africa there is need for a skilled body, the intellectual community, the political community to fashion solutions to address existing challenges. The foregoing can contribute in accelerate the process of integration, enabling the continent play its role in the global economy, address multifaceted social, economic, and political problems via its economic development. This conceptual model captures issues discussed in this work in relation to knowledge creation and learning for development.

In the face of unharnessed opportunities to prepare youths for citizenship, lack of innovation, loss of capacity: the twenty-first century offers potential to reaffirm the role of education with a view to equipping younger and older learners to address complex societal, economic, and environmental issues. The transformation from teacher-led to selfdetermined, self-directed learning will provide learners with a range of competencies and skills needed to succeed in the modern global economy. Personalized and tailored instruction helps learners to reach full potential; prepares them to interact with their own communities, virtually and beyond, confidently relate with persons of diverse cultures, while continuing to learn throughout their lives. Education should prepare learners for collaboration, problem-solving scenarios that are persistent and lack clear solutions. Real-world challenges are highly complex, often ill-defined and interdisciplinary in nature, spanning multiple domains (social, economic, political, environmental, legal and ethical). Learners need opportunities to reflect on their ideas, hone analytical skills, strengthen critical and creative thinking capacities, as well as demonstrate initiative. The ability to evaluate new inputs and perspectives, build new capacities and strengthen autonomy is crucial. Neither teachers can overhaul the education system on their own, nor can nations counteract worldwide deficiencies in education systems in isolation. Consequently, nations need to collaborate in order to avoid the impending consequences if today's learners are not adequately prepared to collaboratively 
resolve the world's economic, environmental, health, social, and political challenges. Nations need to form alliances in order to overcome obstacles to overhaul education; each nation need to examine new ideas from its citizens, increase the collective impact, and innovatively tackle these challenges through regional partnerships, and coalitions that accommodate local needs and contexts. The elements and benefits of promising practices and innovations can be shared and those that work can be replicated. Ultimately, the difficult work of radically transforming learning can be leveraged through international networks.

The role of schools in the future and their capacity to radically transform themselves remains uncertain: far from proclaiming their impending obsolescence, it is better to rethink the role of schools as a public resource and radically re-imagine how they can evolve. Nations must acknowledge the many reasons why twenty-first century learning must be different. They need to critically evaluate traditional education to determine whether schools are living up to current expectations and ask how successful their schools actually are in equipping students to compete in a global economy. Every nation has its vision of twenty-first century education; many are aware of new methods that have enjoyed at least some success in their region, both in terms of pedagogy and teacher development. Trilling and Fadel (2009) assert that every nation can contribute to a global pool of expertise on how best to implement twenty-first century learning. Investment that produces successful learning innovations in one nation can have a ripple effect as other nations adopt and adapt these methods for their own use. With increased international cooperation and collaboration, each nation can participate in building a global learning network as dominant and pervasive as existing international networks in business, finance, and communications. There is broad agreement that in addition to literacy and numeracy, twenty-first century learning must include transferable skills such as critical thinking, problem-solving, and civic values that prepare young people for the workforce and active participation as informed citizens (Anderson, 2014; Leadbeater and Wong, 2010). This concern is now clearly reflected among the education targets being proposed as part of the global Sustainable Development Goals being proposed for 2030.

\section{REFERENCES}

1) Ala-Mutka, K., Redecker, C., Punie, Y., Ferrari, A., Cachia, R. and Centeno, C. 2010. The Future of Learning: European Teachers' Visions. JRC Scientific and Technical Reports. Luxembourg, Publications Office of the European Union.

2) Anderson, A. 2014. Southern perspectives on learning and equity in the post-2015 sustainable development agenda.

3) Bates, A.W. 2011. Understanding Web 2.0 and its implications for e-learning. M. Lee and $\mathrm{C}$. McLoughlin (eds), Web 2.0-Based E-Learning: Applying Social Informatics for Tertiary Teaching. Hershey, Penn., Idea Group Inc.

4) Ben-David Kolikant, Y. 2010. Digital natives, better learners? Students' beliefs about how the Internet influenced their ability to learn. Computers in Human Behavior, Vol. 26, pp. 1384-1391.

5) Bolstad, R. 2011. Taking a 'Future Focus' in Education - What Does It Mean? NZCER Working Paper. Wellington, New Zealand Council for Educational Research.

6) Brown, J.S. and Adler, R.P. 2008. Minds on fire: open education, the long tail, and Learning 2.0. EDUCAUSE Review, January/ February, pp. 1732.

7) Buckingham, D. 2007. Beyond Technology: Children's Learning in the Age of Digital Culture. Cambridge, UK, Polity Press.

8) Bull, A. and Gilbert, J. 2012. Swimming Out of Our Depth: Leading Learning in 21st Century Schools. Wellington, New Zealand Council for Educational Research.

9) Carneiro, R. 2007. The big picture: understanding learning and meta-learning challenges. European Journal of Education, Vol. 42, No. 2, pp. 151-172.

10) Crompton, H. 2012. How Web 2.0 is changing the way students learn: the Darwikinism and Folksonomy revolution.

11) Davidson, C.N. and Goldberg, D.T. with the assistance of Jones, Z.M. 2009. The Future of Learning Institutions in a Digital Age. MacArthur Foundation Reports on Digital Media and Learning.

12) Davies, A., Fidler, D. and Gorbis, M. 2011. Future Work Skills 2020. Palo Alto, Calif., University of Phoenix Research Institute.

13) Delors, J., Al Mufti, I., Amagi, I., Carneiro, R., Chiung, F., Geremek, B., Gorham, W., Kornhauser, A., Manley, M., PadrónQuero, M., 
Savané, M-A., Singh, K., Stavenhagen, R., Won Suhr, M. and Nanzhao, Z. 1996. Learning: The Treasure Within: Report to UNESCO of the International Commission on Education for the Twenty-First Century.

14) Facer, K. 2011. Learning Futures: Education, Technology and Social Change. New York, Routledge.

15) Facer, K. and Sandford, R. 2010. The next 25 years? Future scenarios and future directions for education and technology. Journal of Computer Assisted Learning,

16) Gijsbers, G. and van Schoonhoven, B. 2012. The future of learning: a foresight study on new ways to learn new skills for future jobs. European Foresight Platform (EFP) Brief, No. 222.

17) Grimus, M. and Ebner, M. 2013. M-Learning in the SubSaharan Africa context: what is it about? World Conference on Educational Multimedia, Hypermedia and Telecommunications,

18) Herring, S. 2012. Transforming the workplace: critical skills and learning methods for the successful 21 st century worker. Big Think (online).

19) ITU and UNESCO. 2014. SIS Newslog - Mobile Learning Week: A Revolution for Inclusive \& Better Education (online). Geneva, International Telecommunication Union.

20) Klamma, R., Cao, Y. and Spaniol, M. 2007. Watching the blogosphere: knowledge sharing in Web 2.0. Proceedings of the International Conference on Weblogs and Social Media.

21) Lee, M.J.W. and McLoughlin, C. 2007. Teaching and learning in the Web 2.0 era: empowering students through learnergenerated content. International Journal of Instructional Technology \& Distance Learning, Vol. 4, No. 10, pp. 21-34.

22) Mandioma, M.T., Krishna, G.S.V., Terzoli, A. \&Muyingi, H. (2007). Deployment of WiMax for telecommunications and internet access in DwesaCwebe rural areas.

23) McLoughlin, C. and Lee, M.J.W. 2007. Social software and participatory learning: pedagogical choices with technology affordances in the Web 2.0 era. ICT: Providing Choices for Learners and Learning: Proceedings Ascilite Singapore 2007, pp. 664-675.

24) Mohamedbhai G. (2008) "The Role of Higher Education for Human and Social Development in Sub-Saharan Africa" in GUNI Higher Education in the World 3 Basingstoke: Palgrave.
25) NDPC. 2005. Information About the School Dropout Issue: Selected Facts \& Statistics. Clemson, SC, National Dropout Prevention Center.

26) NEPAD (New Partnership for Africa's Development). 2005. Renewal of Higher Education in Africa. Report of AU/NEPAD Workshop 27-28 October, in Johannesburg.

27) P21. 2007. The Intellectual and Policy Foundations of the 21st Century Skills Framework. Washington DC, Partnership for 21st Century Skills.

28) Punie, Y. 2007. Learning spaces: an ICT-enabled model of future learning in the knowledge-based society. European Journal of Education,

29) Redecker, C., Ala-Mutka, K., Leis, M., Leendertse, M., Punie, Y., Gijsbers, G., Kirschner, P., Stoyanov, S. and Hoogveld, B. 2010. The Future of Learning: New Ways to Learn New Skills for Future Jobs - Results from an Online Expert Consultation.

30) Saavedra, A. and Opfer, V. 2012. Teaching and Learning 21st Century Skills: Lessons from the Learning Sciences. A Global Cities Education Network Report. New York, Asia Society.

31) Sawyer, R.K. 2006. Educating for innovation. Thinking Skills and Creativity, Vol.1, pp. 41-48.

32) Sawyerr, A. (2004) 'Challenges facing African universities: selected issues', African Studies Review 47(1): 1-59.

33) Selwyn, N. and Facer, K. 2013. The need for a politics of education and technology. N. Selwyn and K. Facer (eds), The Politics of Education and Technology: Conflicts, Controversies, and Connections. New York, Palgrave Macmillan, pp. 1-17.

34) Sharpe, R., Beetham, H. and de Freitas, S. (eds), 2010. Rethinking Learning for a Digital Age: How Learners are Shaping their Own Experiences. New York, Routledge.

35) Tchombe (in Press). New ways of knowing, new practices and forms of provisions for inclusive equity education: The importance of collaborative action research

36) UNESCO (2010). Why and how Africa should invest in African languages and multilingual education An evidence- and practice-based policy advocacy brief. By AdamaOuane and Christine Glanz Developed in collaboration with the Association for the Development of Education in Africa (ADEA) and UNESCO Institute for Lifelong Learning 
37) UNESCO (2015a). Education for All Global Monitoring Report. Paris

38) UNESCO (2015b). World Education Forum, Jomtien: Final Report. 7, place de Fontenoy, 75352 Paris 07 SP, France.

39) UNESCO Institute for Statistics (2017). School resources and learning environment in Africa Key results from a regional survey on factors affecting quality of education. Retrieved from http://uis.unesco.org/en/topic/education-africa.

40) United Nations (2008b). Population Division, the Department of Economic and Social Affairs

41) United Nations Capital Development Fund (UNCDF). (2000). Africa: Decentralisation and Local Governance Conference Concept Paper. Draft paper for the UNCDF Symposium on Decentralization and Local Governance in Africa, Cape Town, South Africa, 26-30 March. UNCDF, New York.

42) United Nations. (2008a). An Overview of Urbanization, Internal Migration, Population Distribution and Development in the World. United Nations Expert Group Meeting on Population Distribution, Urbanization, Internal Migration and Development. New York, 21-23 January 2008.

43) Willms, J.D., Friesen, S. and Milton, P. 2009. What Did You Do in School Today? Transforming Classrooms through Social, Academic, and Intellectual Engagement. First National Report. Toronto, Ont., Canadian Education Association.

44) Yazzie-Mintz, E. 2010. Charting the Path from Engagement to Achievement: A Report in the 2009 High School Survey of Student Engagement. Bloomington, Ind., Indiana University Center for Evaluation and Education Policy. 